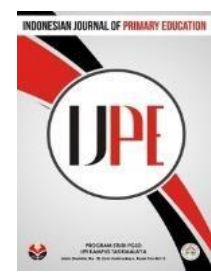

Vol. 1, No. 2 (2017) 95-104 ISSN: 2597-4866

Indonesian Journal of Primary Education

\title{
Pendidikan Karakter \\ melalui Cerita Rakyat pada Siswa Sekolah Dasar
}

\author{
Vit Ardhyantama \\ STKIP PGRI Pacitan \\ vit.10276@gmail.com
}

Diterima 31 Agustus 2017; Direview 28 September 2017; Diterima 24 Oktober 2017

Diterbitkan online 26 Desember 2017

\begin{abstract}
Moral degradation of the Indonesian nation is reflected in the many social deviations that occur in society, from the young to the old. Indonesia is facing a moral crisis that is not in line with Pancasila's mandate. Gangs that have been done down and down by Indonesian students, now even have penetrated to elementary school. Looking back at the various problems that hit the country then it is time we look back on the importance of character education for the nation of Indonesia. The character of Indonesian nation either implicitly or explicitly has been told in the folklorethat have been passed down from generation to generation to Indonesian grandchild since ancient times. Folklore besides appealing to elementary school children is also full of values and culture. Library research method used to go deep into character buliding of elementary school children through folklore. Using folklore as a character-former in a child is more easily accepted and away from the impression of coercion. The child's character can be formed from either the implied or the written messages in the story and through the behavior of the characters depicted in the story.
\end{abstract}

Keywords: Character Building; Folklore; Elementary Students

\begin{abstract}
Abstrak
Degradasi moral bangsa Indonesia tercermin dari banyaknya penyimpangan sosial yang terjadi dalam masyarakat, baik dari kalangan muda sampai kalangan tua. Indonesia sedang menghadapi krisis moral yang amat tidak sesuai dengan amanat Pancasila. Tawuran yang sudah dilakukan secara turun menurun oleh pelajar Indonesia, kini bahkan sudah merambah ke anak usia SD. Menengok kembali berbagai permasalahan yang melanda negeri ini maka sudah saatnya kita melihat kembali betapa pentingnya pendidikan karakter bagi bangsa Indonesia. Karakter bangsa Indonesia baik secara implisit maupun eksplisit sudah diceritakan dalam dongeng-dongeng yang diberikan secara turun temurun kepada anak cucu Indonesia sejak zaman dahulu. Cerita rakyat selain menarik bagi anak usia SD juga sarat akan nilai dan budaya. Metode penelitian kepustakaan digunakan dalam mendalami pendidikan karakter anak SD melalui cerita rakyat. Menggunakan cerita rakyat sebagai pembentuk karakter dalam diri anak lebih mudah diterima dan jauh dari kesan pemaksaan. Karakter anak dapat terbentuk dari pesan-pesan baik tersirat maupun tersurat dalam cerita serta melalui tingkah laku tokoh yang digambarkan dalam cerita.
\end{abstract}

Kata Kunci: Pendidikan Karakter; Cerita Rakyat; Siswa SD

\section{PENDAHULUAN}

Tawuran, bullying, pelecehan terhadap guru, penyalahgunaan social media, penyalahgunaan narkoba, dan korupsi merupakan salah satu dari sekian banyak fenomena sosial yang dapat kita jumpai saat ini. Degradasi moral bangsa Indonesia tercermin dari banyaknya penyimpangan sosial yang terjadi dalam masyarakat, baik dari kalangan muda sampai kalangan tua.
Indonesia sedang menghadapi krisis moral yang amat tidak sesuai dengan amanat Pancasila.

$$
\text { Pancasila sebagai ideologi bangsa }
$$

Indonesia sudah kehilangan ruhnya dan terabaikan oleh bangsanya sendiri. Dikatakan dalam sila ketiga Pancasila yaitu "persatuan Indonesia", memiliki makna bahwa ideologi bangsa Indonesia sangat menjunjung tinggi rasa persatuan, tidak mementingkan 
kepentingan golongan, ras, agama namun menjunjung tinggi kepentingan bangsa bersama.

Indonesia dengan beragam budaya, ras, suku, bahasa dan kekayaan alam yang terkandung pada tiap daerah yang tersebar dari sabang sampai merauke adalah sebuah keunikan dan anugerah yang diberikan Tuhan. Keberagaman sebagaimana disepakati pendahulu kita yang tertuang dalam sila ketiga Pancasila adalah anugerah yang dipersatukan dengan satu bangsa yaitu bangsa Indonesia. Hal ini juga disuarakan oleh pemuda Indonesia, pada kongres pemuda II tanggal 27-28 Oktober 1928 yang kita kenal dengan sumpah pemuda.

Hilangnya ruh Pancasila dalam kehidupan bermasyarakat berbangsa dan bernegara saat ini dapat disaksikan dengan mudahnya masyarakat mengadu domba, menyuarakan kalimat-kalimat provokatif, saling mencaci, merendahkan dan menghina. Masyarakat Indonesia seakan lupa bagaimana cara bersopan santun dalam menyuarakan pendapat. "Kerakyatan yang dipimpin oleh hikmat kebijaksanaan dalam permusyawaratan dan perwakilan" seakan hilang ditelan bumi. Tidak ada lagi musyawarah untuk mufakat bagi Indonesia dewasa ini, tiap orang menganggap dirinya paling benar dan melontarkan cacian bagi yang berseberangan pendapat dengannya.

Dukungan media sosial dan teknologi yang makin canggih bukannya dimaanfaatkan untuk memajukan kesejahteraan umum sebagimana tertuang dalam pembukaan UUD, namun digunakan sebagai alat untuk berperang melawan saudara-saudara sebangsa dan setanah airnya sendiri.

Tidak hanya berhenti disini, kemerosotan moral bangsa kita tercermin dari bagaimana generasi muda kita berperilaku. Tawuran yang sudah dilakukan secara turun menurun oleh pelajar Indonesia, kini bahkan sudah merambah ke anak usia SD. Sebagimana diberitakan media Merdeka.com edisi tanggal 27 November 2016, lengkap dengan senjata tajam, anak usia SD di Semarang melakukan tawuran antar sekolah. Pemicunya sudah bukan barang baru lagi, kesalahpahaman yang disebabkan dari tidak adanya kesopansatunan dalam menyampaikan pendapat, berakibat saling mencela dan berujung tawuran.

Generasi muda Indonesia adalah tumpuan kesukesan bangsa melalui pendidikan (Mulyani, Sri: 2016). Akan dibawa kemana bangsa ini kalau anak usia SD nya saja sudah berani melawan gurunya sendiri berlaku tidak sopan serta tidak menghargai ${ }^{1}$. Kasus yang tak kalah hebohnya bahkan melibatkan orangtua murid dalam pengeroyokan terhadap seorang guru ${ }^{2}$. Kasus yang terjadi di Makasar ini sangat mencoreng citra pendidikan Indonesia. Kurangnya dukungan orangtua terhadap pendidikan anaknya serta kuranganya komunikasi yang terjalin antara orangtua dengan guru memicu terjadinya peristiwa ini.

Sebagaimana kita tahu pendidikan bukan hanya diserahkan di pundak bapak ibu guru. 
Pendidikan adalah tugas bersama orangtua, guru serta lingkungan. Seluruh elemen ini memiliki tugas yang sama untuk mendidik anak bangsa meskipun dengan porsi dan bentuk yang berbeda. Pendidikan yang baik adalah pendidikan yang melibatkan semua elemen dalam masyarakat, karena sasaran pengembangan individu bagi peserta didik bukan hanya terbatas pada penguasaan materi saja melainkan menyeluruh mencakup semua segi atau potensi yang dimiliki oleh peserta didik baik itu pribadi yang meliputi perilaku, beragama, perasaan, kemauan pikiran maupun sosial dan jasmani (Pidarta made, 2015:9).

Menengok kembali berbagai permasalahan yang melanda negeri ini maka sudah saatnya kita melihat kembali betapa pentingnya pendidikan karakter bagi bangsa Indonesia. Pentingnya diberikan pendidikan karakter terhadap anak didik sebagaimana pendapat A Koesoema Doni (2007:135) adalah karena pendidikan karakter lebih mengutamakan moral individu yang ada dalam lembaga pendidikan.

Anak didik yang bermoral dan berkarakter akan memiliki pegangan yang kuat sehingga bijak dalam memanfaatkan teknologi serta ilmu yang diperolehnya dan tahan dalam menghadapi tantangan serta persaingan dalam era globalisasi dan teknologi seperti saat ini. Penanaman pendidikan karakter akan menciptakan kerukunan dan persatuan Indonesia sebagaimana sila ketiga Pancasila. Hal ini dikarenakan dalam pendidikan karakter dikembangkan nilai-nilai etika inti seperti kepedulian kejujuran keadilan tanggungjawab dan rasa hormat terhadap diri dan oranglain serta nilai-nilai kinerja pendukung seperti etos kerja yang tinggi dan kegigihan sebagai basis karakter yang baik (Maksudin, 2013:126).

Meskipun pendidikan karakter mengutamakan moral peserta didik bukan berarti meninggalkan kualitas keilmuan yang seharusnya diberikan kepada mereka. Melalui penanaman karakter peserta didik diajarkan untuk menghargai proses belajar itu sendiri seperti dikemukakan oleh Kesuma dkk (2012:81) bahwa pendidikan karakter dalam ruang kelas mengembangkan the conscience of craft dengan menumbuhkan tanggungjawab akademik para siswa dan penghargaan mereka terhadap nilai dari belajar dan bekerja.

Karakter seperti apakah kemudian yang akan dibentuk bagi generasi bangsa Indonesia. Karakter yang dibentuk bagi generasi penerus bangsa Indonesia tentu saja karakter yang mencerminkan ideologi luhur bangsa, yaitu Pancasila. Kaelan (2002:2) menyatakan bahwa bangsa Indonesia memiliki pandangan hidup yang berbeda dengan bangsa lain yang meliputi mengakui dzat mutlak (yaitu Tuhan), humanisme, nasionalisme mewujudkan persamaan serta keadilan dalam hidup bersama Karakter yang mencerminkan ideologi bangsa inilah minimal yang harus diberikan kepada anak didik.

Karakter bangsa Indonesia baik secara 
implisit maupun eksplisit sudah diceritakan dalam dongeng-dongeng yang diberikan secara turun temurun kepada anak cucu Indonesia sejak zaman dahulu. Cerita rakyat yang kita bacakan pada anak-anak kita sebelum tidur meskipun sayangnya karena alasan kesibukan orangtua semakin jarang ditemui acara mendongeng sebelum tidur oleh orang tua kepada anaknya, terkandung nilainilai luhur bangsa Indonesia yang akan disampaikan kepada generasi penerusnya.

Cerita rakyat selain menarik bagi anak usia SD juga sarat akan nilai dan budaya. Cerita rakyat sebagai bagian dari sastra lisan memiliki empat fungsi yang dua diantaranya adalah berfungsi sebagai alat pemaksa berlakunya norma-norma sosial dan sebagai alat kontrol sosial serta sebagai alat pendidikan anak (Emzir dan Saifur, 2015:229-230). Cerita rakyat dengan demikian sekiranya dapat digunakan sebagai pengantar dalam menanamkan karakter bagi anak didik usia SD. Meski demikian perlu dilakukan studi lebih mendalam untuk mengetahui apakah cerita rakyat dapat digunakan dalam mengajarkan karakter pada anak usia SD.

\section{METODE PENELITIAN}

Penelitian ini mengunakan metode kepustakaan atau studi literatur yaitu mempelajari buku-buku referensi dan hasil penelitian sejenis sebelumnya yang pernah dilakukan oleh orang lain (Sarwono, 2006:26). Studi literatur selain dari mencari sumber data sekunder yang akan mendukung penelitian juga diperlukan untuk mengetahui sampai mana ilmu yang berhubungan dengan penelitian telah berkembang, sampai ke mana terdapat kesimpulan dan degeneralisasi yang telah pernah dibuat, sehingga situasi yang diperlukan dapat diperoleh (Nazir, 2003:92).

Sumber data primer dalam penelitian ini adalah buku-buku dan jurnal serta artikel yang membahas tentang cerita rakyat dan pendidikan karakter. Adapun sumber data sekunder diambil dari sumber serupa yang memiliki keterkaitan dengan objek penelitian ini.

Analisis data dilakukan dengan cara deskriptif analisis. Data yang sudah terkumpul akan dianalisis untuk kemudian ditarik sebuah simpulan yang akan digunakan untuk menjawab pertanyaan dalam penelitian.

\section{HASIL DAN PEMBAHASAN \\ 1. Pendidikan Karakter}

Pendidikan merupakan usaha sadar yang dimaksudkan untuk memperbaiki kualitas kehidupan manusia. Ada beberapa teori belajar yang disampaikan oleh para ahli. Tiap teori belajar ini memiliki orientasi, sudut pandang, cara pengajaran serta tujuan yang berbeda menurut keyakinannya masingmasing.

Gagne (dalam Sanjaya, 2008:233) menjelaskan ada lima jenis atau tipe yang diharapkan sebagai hasil dari belajar yaitu belajar kemahiran intelektual (kognitif), belajar invormasi verbal, belajar mengatur kegiatan intelektual, belajar sikap serta belajar motorik. Tertuang dalam lampiran permendikbud No. 54 tahun 2013 tentang 
tentang standar kompetensi lulusan pendidikan dasar dan menengah, dapat kita lihat pula bahwa ranah pembelajaran dalam dunia pendidikan di Indonesia bukan hanya berada di sekitar aspek kognitifnya saja, melainkan meliputi pada aspek sikap yang dibagi lagi menjadi dua yaitu sikap terhadap Tuhan yang bersangkutan dengan jiwa kerohanian (KI 1) dan sikap terhadap sesamanya yaitu terkait dengan jiwa kesosialan siswa (KI 2), aspek pengetahuan baik itu faktual maupun konseptual (KI 3) serta aspek keterampilan baik itu dalam berpikir maupun dalam bertindak (KI 4).

Pendidikan dan pembelajaran dengan demikian bukanlah sebuah usaha yang semata-mata bertujuan untuk mengasah kemampuan kognitif melainkan untuk menumbuhkembangkan aspek lain dalam diri anak guna mencapai perkembangan yang optimal dalam diri anak tersebut sebagai bekal untuk menghadapi kehidupannya di masa yang akan datang.

Karakter erat hubungannya dengan sikap. Said (2011:1) mengartikan karakter sebagai mempunyai kualiatas positif seperti peduli, adil, jujur, hormat terhadap sesama, rela memaafkan, sadar akan hidup berkomunitas, dan sebagainya. Lebih lanjut Said (2011:1) menyatakan bahwa karakter lebih banyak menyangkut tentang nilai-nilai moral.

Karakter yang sudah lama digembar gembor kan namun tersisih dalam penerapannya adalah salah satu landasan penting dalam kehidupan. Karakter adalah ciri khas seseorang sehingga menyebabkan ia berbeda dari orang lain secara keseluruhan (Sastrowardoyo dalam Said, 2011:1). Andaikan ada sebuah kasus dimana disuguhkan pada dua orang memiliki kecerdasan dan kemampuan berpikir yang sama maka yang membedakan tindakan dari keduanya adalah karakter yang ada dalam orang tersebut. Karakter berfungsi sebagai alat pengatur dan pengendali dalam berpikir maupun bertindak yang kemudian mewarnai keputusan dan tindakan yang akan dilakukan oleh orang tersebut berdasarkan karakter yang terbentuk di dalam dirinya.

Karakter memiliki kedudukan yang lebih tinggi dari kemampuan intektual yang berada dalam ranah kognitif. Ralph Waldo Emerson (dalam Lickona, 2004:4) pada sebuah kuliah di Universitas Harvard menegaskan bahwa karakter lebih tinggi daripada intelek. Kehidupan keseharian kita dalam berkehidupan sosial, karir dan bidang lainnya juga sangat ditentukan dari karakter diri kita masing-masing. Psikiater Frank Pittman (dalam Lickona, 2004:4) mengatakan bahwa karakterlah yang memungkinkan orang mampu untuk bertahan hidup, memikul dan mengatasi kemalangan mereka.

Karakter dapat terbentuk dari pembiasaan. Semakin dini pembiasaan diajarkan maka akan semakin kuat karakter tersebut tumbuh dalam diri anak. Anak usia SD kelas rendah sebagaimana dijelaskan oleh Hurlock (2002:123) bahwa perkembangan sosial awal masa kanak-kanak masih dalam tingkat yang 
rendah. Piaget (dalam Hurlock, 2002:123) menyebut massa ini dengan moralitas melalui paksaan. Anak SD kelas awal memiliki perkembangan intelektual yang masih rendah sehingga sedikit kesulitan untuk menemukan sebuah alasan mengapa sesuatu boleh dilakukan atau tidak. Perkembangan moral anak usia kelas rendah ini masih perlu pengawalan yang ketat oleh guru dan orangtua. Mereka harus dapat menjelaskan mengapa anak boleh melakukan sesuatu atau tidak dengan alasan logis yang dapat diterima anak. Pemaksaan untuk meninggalkan aktivitas yang bernilai buruk dan melakukan kebajikan perlu dilakukan untuk membiasakan dan mendisiplinkan anak. Tujuan dari kegiatan ini adalah agar terbentuk dalam diri anak bahwa hanya kegiatan yang bernilai baik saja yang boleh dia lakukan meskipun ada beberapa hal yang anak sendiri belum memahami maksud dan sebab dibolehkan atau tidaknya suatu tindakan anak tersebut.

Anak SD kelas tinggi sudah memiliki kemampuan analisis sederhana. Mereka dapat menyimpulkan alasan mengapa mereka boleh atau tidak melakukan suatu tindakan. Anak dalam usia ini sudah mampu mengembangkan makna baik buruk dan benar salah yang sudah diajarkan pada usia sebelumnya. Hurlock (2002:163) mengemukakan bahwa konsep moral pada akhir masa kanak-kanak tidal lagi sesempit dan sekhusus sebelumnya.

\section{Cerita Rakyat untuk Menanamkan Karaker}

Cerita rakyat merupakan salah satu anggota keluarga dari karya sastra. Sastra penting dalam pendidikan karena sastra dapat menunjukkan kebenaran hidup, memperkaya rohani, melampaui batas bangsa dan zaman, sebagai media pengajaran untuk santun berbahasa serta dapat menjadikan manusia berbudaya (Zulela, 2013:20-23). Kelima manfaat sastra dalam pendidikan ini dapat membangun karakter yang baik bagi siswa.

Kebenaran hidup yang disuguhkan dalam cerita rakyat tentunya dapat dijadikan contoh bagi anak untuk berperilaku sebagaimana tokoh protagonis dalam cerita. Anak akan terstimulus melakukan tindakan-tindakan yang terpuji setelah mendengar cerita yang berkisah tentang bagimana akhir yang baik bagi pelaku yang baik. Sebalikya anak akan mendapatkan gambaran bagimana akhir dari tokoh yang berperilaku kurang baik sehingga anak-anak cenderung akan menjauhi perilakuperilaku yang kurang terpuji.

Cerita rakyat sudah hidup dan tumbuh sejak zaman dahulu sehingga dapat kita jumpai ada banyak sekali cerita rakyat baik yang sudah ditulis maupun yang diwariskan secara lisan. Dua dari empat fungsi tradisi lisan, termasuk di dalamnya adalah cerita rakyat menurut Emzir dan Saifur (2015:229230) adalah berfungsi sebagai alat pemaksa berlakunya norma-norma sosial yaitu sebagai alat kontrol sosial serta sebagai alat pendidikan anak.

Norma sosial dengan demikian dapat 
diajarkan kepada anak melalui cerita rakyat. Cerita rakyat Rorojonggrang misalnya mengajaran kepada kita bahwa seorang ratu yang baik akan mendapatkan bantuan dengan mudah dari dayang dan rakyatnya. Nilai sosial yang terkandung dalam cerita Rorojongrang ini berlaku bukan hanya untuk seorang ratu namun juga untuk rakyat biasa seperti kita. Nilai yang dapat dipetik dari cerita rakyat tersebut adalah siapa yang berperilaku baik terhadap sesamanya maka akan diperlakukan dengan baik serta mudah mendapatkan pertolongan.

Norma dan nilai yang tersirat dalam cerita rakyat tidak selamanya mudah ditangkap dan dicerna oleh anak. Guru dan orangtua sebaiknya ikut mendampingi anak dalam menikmati cerita rakyat, hal ini dilakukan agar anak dapat dibimbing dalam mencari dan menelaah makna dari cerita rakyat yang telah didengar ataupun dibacanya.

Pemberian pertanyaan-pertanyaan yang mengarah pada pembelajaran karakter perlu diberikan pada anak setelah kegiatan mendongeng selesai atau bahkan pada saat kegiatan sedang berlangsung. Anak akan menemukan sendiri karakter yang baik dari cerita dengan bantuan guru atau orangtua.

Menggunakan cerita rakyat sebagai pembentuk karakter dalam diri anak lebih mudah diterima dan jauh dari kesan pemaksaan. Karakter anak dapat terbentuk dari pesan-pesan baik tersirat maupun tersirat dalam cerita serta melalui tingkah laku tokoh yang digambarkan dalam cerita.
Legenda asal mula nama kota Surabaya misalnya mengisahkan bagaimana kerugian yang diakibatkan oleh perkelahian atau pertengkaran. Dikisahkan bagaimana ikan Hiu Sura dan Buaya berkelahi memperebutkan kekuasaan sehingga mengakibatkan keduanya mati sia-sia

Cerita rakyat Sura dan Baya yang berasal dari Jawa Timur ini dapat digunakan sebagai perantara bagi guru dan orangtua untuk mengajarkan kepada anak bahwa dalam menyelesaikan masalah baiknya dilakukan dengan musyawarah. Perkelahian tidak akan menyelesaikan masalah justru menimbulkan masalah baru serta memperkeruh masalah yang telah ada. Perkelahian Sura dan Baya dapat dijadikan contoh bagi anak bahwa masalah persengketaan antara keduanya tidak terselesaikan justru membawa mereka kedalam petaka yaitu kematian. Berawal dari kisah ini anak akan dibimbing untuk belajar mengasihi sesama, berlaku sopan, saling menghargai dan berpikir sebelum bertindak.

Satu cerita rakyat dapat mengantarkan dan membentuk pribadi dan karakter yang baik bagi anak. Sifat atau watak dalam tokoh dalamcerita rakyat juga dapat digunakan guru dan orangtua dalam membangun karakter anak. Bagaimana Baya merasa dirugikan dan dikhianati oleh Sura sehingga Ia menantang Baya berduel hingga akhirnya menemui ajal merupakan salah satu contoh bahwa kita harus membela kebenaran dan harga diri kita, meskipun dalam cerita ini solusi yang ditawarkan kurang tepat yaitu melalui 
perkelahian namun tetap terkandung di dalamnya bahwa membela kebenaran dan harga diri adalah hal yang penting.

Peran guru dan orangtua sekali lagi dengan demikian adalah menuntun anak. Apabila dirasa dalam cerita menunjukkan sesuatu yang belum tepat yaitu penyelesaian masalah melalui perkelahian, orang tua dan guru harus menjelaskan pada anak bahwa ini merupakan contoh yang salah dan mengakibatkan kerugian pada keduanya pada akhir cerita. Anak akan meresapi serta merenungkan cerita ini beserta penjelasan yang telah diberikan oleh guru dan orangtua.

Proses menikmati cerita rakyat akan menimbulkan banyak pertanyaan dalam benak anak. Biasanya anak akan banyak mempertanyakan implikasi dan alasan yang logis dan dapat diterima mereka mengenai tindak tanduk tokoh yang muncul dalam cerita.

Setiap perbuatan yang digambarkan dalam cerita rakyat mengandung makna yang akan bermanfaat bagi perkembangan anak baik dari sisi psikologis, kognitif maupun sosial. Kesalahan penafsiran akan menjadi hal yang fatal bagi kehidupan anak keseharian. Dengan demikian penafsiran dan pemaknaan isi dari cerita rakyat ini harus berada di bawah bimbingan dan pengawasan guru atau orangtua.

Transferability makna cerita rakyat ke dalam kehidupan nyata anak perlu dibiasakan. Apapun kegiatan yang dilakukan anak, mengaitkan tindakan anak dengan cerita yang sudah dibacakan kepada anak adalah perlu untuk membimbing tumbuhnya karakter baik dalam anak. Digunakan cerita rakyat untuk mendukung atau menyatakan keberatan dengan tindakan anak adalah pilihan bijaksana karena anak tidak akan merasa tertekan dan dikekang karena dalam benak anak sudah tertanam bahwa Ia telah menyetejui perbuatan tokoh dalam cerita yang sudah dibacanya apakah benar atau salah.

Karakter gigih, rendah hati, mau kerjasama dan sopan juga dapat ditanamkan dalam diri anak melalui cerita rakyat. Cerita kera dan ayam dari sulawesi tenggara yang mengisahkan kecerdikan ayam dalam membujuk kera agar mau masuk dalam perahu kemudian disusul adegan kegigihan ayam dan kepiting dalam melubangi perahu untuk menyelamatkan diri dapat digunakan untuk menumbuhkan beberapa karakter tersebut.

Kegigihan ayam dan kepiting dalam melubangi perahu dapat dianalogikan sebagai kegigihan anak dalam belajar untuk meraih cita-cita dan keberhasilan dalam menyelamatkan diri dalam cerita tersebut dalam dianalogikan sebagai cita-cita anak saat besar nanti yang akan tercapai dengan giatnya belajar.

Kerjasama ayam dan kepiting dalam melubangi perahu adalah contoh yang baik bagi anak untuk dapat bekerjasama dengan temannya dalam hal kebaikan. Kerjasama akan mempermudah dalam meraih hasil yang diinginkan dan ini dapat ditanamkan dalam 
diri anak melalui cerita rakyat ayam dan kera.

\section{SIMPULAN}

Karakter dapat terbentuk dari pembiasaan. Semakin dini pembiasaan diajarkan maka akan semakin kuat karakter tersebut tumbuh dalam diri anak. Anak SD kelas awal memiliki perkembangan intelektual yang masih rendah sehingga sedikit kesulitan untuk menemukan sebuah alasan mengapa sesuatu boleh dilakukan atau tidak. Perkembangan moral anak usia kelas rendah ini masih perlu pengawalan yang ketat oleh guru dan orangtua. Mereka harus dapat menjelaskan mengapa anak boleh melakukan sesuatu atau tidak dengan alasan logis yang dapat diterima anak. Pemaksaan untuk meninggalkan aktivitas yang bernilai buruk dan melakukan kebajikan perlu dilakukan untuk membiasakan dan mendisiplinkan anak.

Cerita rakyat merupakan sebuah karya sastra yang dekat dengan anak. Diambil dari cerita-cerita yang banyak beredar di masyarakat, cerita rakyat mudah dinikmati oleh anak. Karakter dan adegan yang ada dalam cerita rakyat dapat dijadikan contoh dan mediator guru serta orangtua untuk mengajarkan karakter baik pada anak. Bukan hanya karakter bagus yang dapat dijadikan contoh pada anak, dalam cerita rakyat biasanya juga terkandung perbuatan tercela yang bisa digunakan orangtua untuk mengingatkan anak akan konsekuensi dari perbuatan tersebut. Dengan demikian maka pembentukan karakter sejak dini dapat dengan mudah dilakukan melalui cerita rakyat.
Hasil dan Pembahasan ditulis dengan huruf Kapital, jarak 1 spasi dan ditebalkan. Simpulan hendaknya merupakan jawaban atas pertanyaan penelitian, dan diungkapkan bukan dalam kalimat stastistik.

\section{DAFTAR PUSTAKA}

Emzir \& Saifur, R. (2015). Teori dan Pengajaran Sastra. Jakarta: Raja Grafindo Persada.

Esy. (2016). Pak Dasrul Dianiaya, Dirjen Guru : Jangan Damai Dulu!. [online]. Diakses dari https://www.jpnn.com/news/pakdasrul dianiaya-dirjen-guru-jangandamai-dulu?page $=1$

Hurlock, E. B. (2002). Psikologi Prkembangan: Suatu Pendekatan Sepanjang Rentang Kehidupan. Jakarta: Erlangga.

Kaelan. (2002). Filsafat Pancasila Pandangan Hidup Bangsa Indonesia. Yogyakarta: Paradigma.

Kesuma, D.C.T.J.P. (2012). Pendidikan Karakter Kajian Teori dan Praktik di Sekolah. Bandung: Remaja Rosdakarya.

Koesoema, D. (2007). Pendidikan Karakter Strategi Mendidik Anak di Era Global. Jakarta: Grasindo

Lickona, T. (2004). Pendidikan Karakter. Bantul: Kreasi Wacana.

Maksudin. (2013). Pendidikan Karakter Nondikotomik. Yogyakarta: Pustaka Pelajar.

Mendikbud. (2013). Permendikbud No. 54 tahun 2013 tentang tentang standar kompetensi lulusan pendidikan dasar dan menengah. Jakarta: Depdikbud.

Nazir, M. (2003). Metode Penelitian. Jakarta: Ghallia Indonesia. 
Pratomo, Y. (2016). Video siswa SD berani tantang guru saat diomeli. [online]. Diakses dari https://www.merdeka.com/peristiwa/vi deo-siswa-sd-berani-tantang-gurusaat-diomeli.html

Pidarta, M. (2015). Wawasan Pendidikan. Unesa: University Press.

Said. (2011). Pendidikan Karakter di Sekolah. Surabaya: Jaring Pena.

Sanjaya, W. (2008). Kurikulum dan Pembelajaran: Teori dan Praktik Pengembangan Kurikulum Tingkat Satuan Pendidikan (KTSP). Jakarta: Kencana.

Sarwono, J. (2006). Metode Penelitian Kuantitatif dan Kualitatif. Yogyakarta: Graha Ilmu.

Zulela. (2013). Pembelajaran Bahasa Indonesia: Apresisasi Sastra di Sekolah Dasar. Bandung: Remaja Rosdakarya. 